\title{
Developing The Evaluation Scale of Female School Administrators
}

\author{
Emel Tüzel İşeri \\ Ohttps://orcid.org/0000-0001-5638-0450 \\ ${ }_{1}^{1}$ Tokat Gaziosmanpaşa University, Turkey \\ *e-mail: emeltuzel@hotmail.com
}

\begin{tabular}{l} 
Article Informat \\
\hline Received: June 08, 2021 \\
Revised: June 28, 2021 \\
Accepted: June 28, 2021 \\
Online: August 10, 2021
\end{tabular}

\section{Keywords}

Female administrators, female school administrators, school administrators

\begin{abstract}
This study aims to present a measurement tool that will be used to measure the female stereotypes faced by women managers in the school organization, how women managers are perceived and how teachers evaluate the school administrators. The study group consisted of 221 teachers working in primary schools in Ankara. As a result of the analysis, a measurement tool consisting of 45 items and five sub-factors including "General Management Success," "Authority Provision and Impact on Interpersonal Relations," "Personality Characteristics," "Family Life," and "Objectivity and Equal Treatment" has been introduced. The Cronbach Alpha reliability coefficients of the factors were calculated as. 96, .94, .93, .94, .90 and. 98 for all items. The variances explained by the factors were 19.797\%, 13.190\%, 12.529\%, $12.127 \%$ and $11.122 \%$ respectively. The total variance of the five factors was determined as $68.765 \%$. The results show that the scale structure has been validated and can be used as a valid and reliable tool in determining teachers' evaluations among female school administrators.
\end{abstract}

\section{INTRODUCTION}

Gender, in a not-so-distant past, took place in almost all institutional classifications. Almost all managers are male; blue-collar workers are male, and lower-level white-collar workers are female. Audit practices and wage-setting processes are shaped by gender and gender assumptions. Although there are women in management levels today, secretaries, civil servants, service providers, and care providers are primarily women in most organizations. Gender and gender assumptions still play important roles in shaping the organizational positions of women and men and blocking women's upper management pathways. According to this, it can be said that in almost all organizations, there have been socially constructed differences between men and women, gender inequalities supported by beliefs, and gender-related identities (Acker, 2009, s. 203).

It has also been the subject of researches in terms of various theories. For example, social role theory focuses on stereotyping gender-related stereotypes depending on the interaction between individuals' gender and social roles. Noting that very few CEOs are women, it investigates why some social roles are associated with a single-gender (Schmidt and Møller, 2011, p. 18).

The attitudes of individuals play a central role in the formation of beliefs and behaviours on various subjects. However, since these attitudes are not observable and concrete, people are often unaware of these attitudes that affect their behaviour. It is seen that most attitudes develop in a rational and unreasonable process but do not comply with any experience or systematic (Yost and Herbert, 1998, p.1). Similarly, individuals categorized people from various groups such as race, gender, physical 
characteristics, educational status, political choice, region, nation, occupational group, disability status, religious belief, age; the fact that people have or can have very different characteristics, it seems that all of them tend to develop stereotypes which can be defined as "Cognitive structures that express knowledge, beliefs, and expectations about a group " which makes them all think like they are showing the same feature or features. In other words, stereotypes are related to the members of a particular group, not the unchanging characteristics of the members, but the mental representations of the social and economic situation of the group (Dökmen, 2004, p. 18-19; Mullins, 2006, p. 172).

The concept of prejudice is defined in the report published by the Equality and Human Rights Commission as "The negative perception of the individual due to its inclusion in any social group" and pointed out that prejudices continue to develop and exist where there are different groups with opposing values, when individuals identify themselves as belonging to particular groups, the group they belong to discriminates against others and see others as different (Abrams, 2010, p. 3).

The stereotypes and prejudices are important that the assumptions arising from stereotypes and prejudices about individuals affect the decisions taken and the important results of these decisions rather than the explanations of the special feelings and thoughts (Bodenhausen ve Richeson, 2010, p.351). Considering that certain distinct social categories construct their perceptions, attitudes, and views towards others and that the gender variable is one of these distinct social categories (Abrams, 2010 , p. 23), it is a fact that individuals are faced with stereotypes and prejudices of gender. In this context, it is possible to mention several stereotypes and prejudices that women face depending on their gender in their managerial positions.

The organization is both a tool to be used by the manager in the management business and an environment in which the manager carries out administrative activities. Like all other administrative tools, the manager needs to know where and how the organization can be used to achieve organizational goals and the organization's limits, features, and dangers.

It can be achieved by having information about the organization and its variables. The changes in the structure and operation of the organization may affect the manager, and the decisions and behaviours of the manager will affect the organization. In this context, it can be said that there are differences in the effect of organizational structures on the behaviour of male and female managers, how the manager is perceived in the organization, and the attitudes of the employees towards the manager (Öztas and Akın, 2009, p. 17).

\section{Purpose of the Study}

This study aims to develop a scale that can be used in school organizations to evaluate teachers about female school administrators, the stereotypes that women managers face, and how teachers perceive women managers.

\section{METHODS}

\section{Determining the Scale Items}

At the stage of determining the scale items of the study, expert opinions were applied, also the "Theoretical Form - Experimental Form" approach was utilized. According to this approach, the draft materials that measure the psychological structure intended to be measured should be determined while creating the theoretical form. All sub-dimensions related to the planned structure are taken into consideration and should be prepared theoretically. In experimental form, the factors are determined which the scale items are produced and under after applying the theoretical form. Also, the items are rearranged within the scope of the representation powers in the factors they are involved in (Tezbaşaran, 1997, by Yurdugül, 2005).

In the process of developing "The Evaluation Scale of Female School Administrators," firstly, the related literature and research results are examined in detail. A draft questionnaire consisting of 138 items was prepared to reveal teachers' perspectives towards female school administrators. A total of six experts, four in educational administration and supervision, one in the field of psychological counselling and guidance, and one in primary school teaching, were asked to evaluate the scope validity and usefulness of the draft scale. According to the expert opinion, a form consisting of 68 questions was obtained by subtracting the items considered similar and not considered necessary to be included in the research. These substances were re-examined and arranged by taking the opinions of two experts in the 
field of measurement and evaluation in education. Application studies were carried out with the scale of the five-point Likert-type (1-Fully disagree, 2-Disagree, 3-Agree at the middle level, 4-Agree and 5Fully agree). In order to determine the personal variables of the participants at the beginning of the questionnaire, a section containing information such as gender, age, professional seniority, etc., was added.

\section{Study Group}

The study was carried out with 250 teachers working in primary schools in Ankara and volunteering to participate in the study. Twenty-nine forms that were either incomplete or not returned to the researcher were excluded from the analysis, and 221 forms were used for developing the scale.

The demographic information of the teachers in the study group was as follows: $36 \%(n=80)$ of the participants were female, and $64 \%(n=141)$ were male. The mean age is 30,4 years and varies between 21 and 56 years. 58\% (n=129) were married, 40\% (n=87) were single and $2 \%(n=5)$ were widowed / divorced. 46\% ( $n=101)$ of the classroom, 54\% of them $(n=120)$ branch teachers. Their service periods are 3.3 years on average, and they have different seniorities between 1-20 years. The average professional seniority is 6.8 years, and there are different participants whose seniorities are between 1-34 years. In the study group, the highest number of teachers graduating from the education faculty was $78 \%(n=172)$. There are teachers from the faculty of science and literature $(\% 10, n=21)$ and teachers from other faculties such as the faculty of economics and administrative sciences, agriculture faculty, etc. $(9 \%, n=20)$. In addition, a small number of teachers graduated from education institutions $(2 \%, \mathrm{n}=5)$ and higher teacher schools $(1 \%, \mathrm{n}=2)$ were also included in the study group. While $92 \%(n=204)$ of the participants did not have postgraduate education degree, $7 \%$ had a master's degree $(\mathrm{n}=16)$ and one participant $(0,5 \%)$ had a PhD degree. Although most of the teachers $(88 \%, \mathrm{n}=$ $195)$ have no managerial experience, $7 \%$ are school principals $(n=14)$, and $6 \%(n=12)$ have the experience of being deputy administrators or chief deputy administrators at schools. $12 \%(n=27)$ of the participants were working with female school principals, other teachers $(88 \%, n=194)$ continue to work with male school principals. One hundred eighty-five of the participants work with only male deputy administrators. There are teachers in the study group working at the schools where just female assistant administrators $(5 \%, \mathrm{n}=12)$ were employed, and teachers working at the schools both female and male deputy principals worked together $(10 \%, \mathrm{n}=24)$.

\section{Operation}

Correlations between items can be shown as evidence that the developed scale is measuring a single structure. For this reason, the data obtained were transferred to the SPSS 11.5 package program, and exploratory factor analysis was performed to determine the existence of a certain order between each participant's responses to the items in the developed scale (Tavsancll, 2010, p.46). As a result of factor analysis, it is aimed to find a conceptually significant, fewer number of variables (factors, dimensions) by combining many variables that are related to each other (Büyüköztürk; 2007, p.117; Cokluk, Șekercioğlu and Büyüköztürk 2010, p.177).

Exploratory factor analysis was performed in three stages. First, a basic component analysis was performed to decide how many sub-factors were structured, and then varimax rotation was performed for determining which items were under which factors. Then the varimax rotation process determines which substances are composed of the factors. In the final stage, the determining factors are examined by their factor loadings and named. Factor analysis was based on a correlation matrix between variables. Therefore, before the factor analysis, the missing values in the very set must be deleted or eliminated according to the estimations (Șencan, 2005, by Cokluk, Șekercioğlu and Büyüköztürk 2010, p.207). The data of the lost data in the data set are applied by linear interpolation.

\section{RESULTS AND DISCUSSION \\ Consequences of Structural Validity and Factor Structures}

Before the research data were subjected to exploratory factor analysis, the suitability of sample size for factorization was investigated by the Kaiser-Meyer-Olkin (KMO) test. KMO and Bartlett's test 
showed a KMO value of .953. The obtained result showed that the sample size is (perfectly sufficient in order to perform factor analysis (C.okluk, Șekercioğlu, and Büyüköztürk, 2010, p.207).

In the factor analysis process, firstly, 68 items were analyzed in order to determine the factor number of the scale, and the eigenvalues, variances, and scree plot graph were examined. Eleven factors with an eigenvalue over one and a contribution of $71.966 \%$ were identified. On the other hand, the contribution of each factor to the variance decreased significantly after the first component (47.051 for the first factor and 3.828 for the second factor). In addition, the scree plot graph was examined, and it was seen that the slope continued from the second point in the form of a plateau. For this reason, it was decided to repeat the analysis process for a single factor.

In the repeated analysis for a single factor, the total contribution of the determining factor to the variance was calculated as $47.051 \%$. When the factor acceptance level was determined for the items, seven items were found to be below. 40, 9, 30, 48, 23, 21, 54 and 10. These substances were extracted, and a scale consisting of 61 items was obtained. Factor loading values of the items of this scale are between. 84 and. 52; item-total correlations ranged from. 51 to. 83. The Cronbach Alpha reliability coefficient was calculated as. 98 . The variance rate of the scale consisting of one factor was calculated as $51.467 \%$.

Due to the accumulation of many items under a single factor, three educational administrations and supervision and measurement and evaluation in education experts were interviewed. As a result of the interviews, the item contents were examined, and it was decided that the single factor scale consisting of 61 items should be subjected to factor analysis under six factors to interpret the teacher evaluations of female managers more in detail. The number of items that are decided to be subjected to factor analysis under six factors in Table 1 is given under the name of "Final Form."

As a result of repeated analysis for six factors, the substances' overlap and factor loading values were evaluated to meet the acceptance level. Nine items $(45,34,57,1,13,14,20,31$, and 33) were overlapped, and one (29) was below the .40 acceptance level. These items were excluded from the analysis to obtain a 51-item scale. When the contribution of the factors included in this scale to total variance was examined, it was found that it was $17.964 \%$ for the first factor, $12.954 \%$ for the second, $12.382 \%$ for the third, $11.062 \%$ for the fourth, $9.839 \%$ for the fifth and $5.023 \%$ for the sixth factor. Considering the low contribution of the sixth factor to the total variance, it was decided to exclude the three items $(19,46$, and 47$)$ included under this factor and repeat the analysis for five factors. As a result of the five-factor analysis, the item distributions and the substance contents of the factors were compared, and it was decided to exclude the three items $(43,42$, and 44$)$, which were found to be incompatible with the same factor.

In the repeated analysis for the five factors, the contribution of the factors in the 45 -item scale to the total variance was $19.797 \%$ for the first factor, $13.190 \%$ for the second, $12.529 \%$ for the third, $12.127 \%$ for the fourth, and $11.122 \%$ for the fifth factor. The total contribution of the five factors to the variance was calculated as $68.765 \%$.

Factor analysis results and Cronbach's Alpha reliability coefficients of the scale consisting of five factors and 45 items were given in Table 1.

Table 1. Factor Analysis and Cronbach's Alpha Reliability Coefficients

\begin{tabular}{|c|c|c|c|c|c|c|c|c|}
\hline \multirow[b]{2}{*}{$\begin{array}{l}\text { Final } \\
\text { Form } \\
\text { No. }\end{array}$} & \multirow[b]{2}{*}{$\begin{array}{l}\text { Pre- } \\
\text { form } \\
\text { No. }\end{array}$} & \multirow[b]{2}{*}{ Items } & \multicolumn{5}{|c|}{ Sub-Factors } & \multirow{2}{*}{$\begin{array}{l}\text { Item Total } \\
\text { Correlations }\end{array}$} \\
\hline & & & $\begin{array}{l}\text { General } \\
\text { management } \\
\text { success }\end{array}$ & $\begin{array}{l}\text { Authority } \\
\text { Prov. and } \\
\text { Imp. On } \\
\text { Int. } \\
\text { per.Rel. }\end{array}$ & $\begin{array}{l}\text { Personality } \\
\text { Characteristics }\end{array}$ & $\begin{array}{l}\text { Family } \\
\text { Life }\end{array}$ & $\begin{array}{l}\text { Objectivity } \\
\text { And Equal } \\
\text { Treatment }\end{array}$ & \\
\hline 16 & 18 & $\begin{array}{l}\text { Male school administrators } \\
\text { exhibit more } \\
\text { active/dynamic } \\
\text { management than female } \\
\text { school administrators. }\end{array}$ & .74 & & & & & .81 \\
\hline
\end{tabular}




\begin{tabular}{|c|c|c|c|c|c|c|c|c|}
\hline \multirow[b]{2}{*}{$\begin{array}{c}\text { Final } \\
\text { Form } \\
\text { No. }\end{array}$} & \multirow[b]{2}{*}{$\begin{array}{c}\text { Pre- } \\
\text { form } \\
\text { No. }\end{array}$} & \multirow[b]{2}{*}{ Items } & \multicolumn{5}{|c|}{ Sub-Factors } & \multirow{2}{*}{$\begin{array}{l}\text { Item Total } \\
\text { Correlations }\end{array}$} \\
\hline & & & $\begin{array}{l}\text { General } \\
\text { management } \\
\text { success }\end{array}$ & $\begin{array}{l}\text { Authority } \\
\text { Prov. and } \\
\text { Imp. On } \\
\text { Int. } \\
\text { per.Rel. }\end{array}$ & $\begin{array}{l}\text { Personality } \\
\text { Characteristics }\end{array}$ & $\begin{array}{l}\text { Family } \\
\text { Life }\end{array}$ & $\begin{array}{l}\text { Objectivity } \\
\text { And Equal } \\
\text { Treatment }\end{array}$ & \\
\hline 14 & 16 & $\begin{array}{l}\text { Male school administrators } \\
\text { are more professional in } \\
\text { management than female } \\
\text { school administrators. }\end{array}$ & .74 & & & & & .86 \\
\hline 22 & 26 & $\begin{array}{l}\text { Female school } \\
\text { administrators exhibit an } \\
\text { undesirable weakness in } \\
\text { matters that need to be } \\
\text { authoritarian. }\end{array}$ & .72 & & & & & .79 \\
\hline 21 & 25 & $\begin{array}{l}\text { Female school } \\
\text { administrators are more } \\
\text { interested in details, so they } \\
\text { are prevented from seeing } \\
\text { the general. }\end{array}$ & .71 & & & & & .79 \\
\hline 23 & 27 & $\begin{array}{l}\text { Female school } \\
\text { administrators are not as } \\
\text { successful as male school } \\
\text { administrators in providing } \\
\text { authority. }\end{array}$ & .70 & & & & & .79 \\
\hline 10 & 12 & $\begin{array}{l}\text { Male administrators in } \\
\text { school management are } \\
\text { more successful than female } \\
\text { administrators. }\end{array}$ & .68 & & & & & .79 \\
\hline 9 & 11 & $\begin{array}{l}\text { Working with a male school } \\
\text { administrator ensures that } \\
\text { things are better at school. }\end{array}$ & .68 & & & & & 74 \\
\hline 19 & 22 & $\begin{array}{l}\text { Female school } \\
\text { administrators have more } \\
\text { panic in the face of } \\
\text { administrative problems. }\end{array}$ & .67 & & & & & .75 \\
\hline 13 & 15 & $\begin{array}{l}\text { Successful school } \\
\text { administrators are } \\
\text { generally male. }\end{array}$ & .67 & & & & & .80 \\
\hline 24 & 28 & $\begin{array}{l}\text { Female school } \\
\text { administrators adopt a } \\
\text { more moderate } \\
\text { management style in the } \\
\text { face of managerial } \\
\text { problems, causing problems } \\
\text { at school. }\end{array}$ & .65 & & & & & .70 \\
\hline 20 & 24 & $\begin{array}{l}\text { Women school } \\
\text { administrators are more } \\
\text { interested in the details, so } \\
\text { works get disrupted. }\end{array}$ & .63 & & & & & .71 \\
\hline 27 & 32 & $\begin{array}{l}\text { Female school } \\
\text { administrators are not as } \\
\text { successful as male school } \\
\text { administrators in coping } \\
\text { with stress. }\end{array}$ & .62 & & & & & .79 \\
\hline 15 & 17 & $\begin{array}{l}\text { Female school } \\
\text { administrators do not have } \\
\text { the leadership skills as male } \\
\text { school administrators have }\end{array}$ & .58 & & & & & .72 \\
\hline 8 & 8 & $\begin{array}{l}\text { Male school administrators } \\
\text { are more successful in } \\
\text { decision making than } \\
\text { female school } \\
\text { administrators. }\end{array}$ & .55 & & & & & .71 \\
\hline
\end{tabular}




\begin{tabular}{|c|c|c|c|c|c|c|c|c|}
\hline \multirow[b]{2}{*}{$\begin{array}{l}\text { Final } \\
\text { Form } \\
\text { No. }\end{array}$} & \multirow[b]{2}{*}{$\begin{array}{l}\text { Pre- } \\
\text { form } \\
\text { No. }\end{array}$} & \multirow[b]{2}{*}{ Items } & \multicolumn{5}{|c|}{ Sub-Factors } & \multirow{2}{*}{$\begin{array}{l}\text { Item Total } \\
\text { Correlations }\end{array}$} \\
\hline & & & $\begin{array}{l}\text { General } \\
\text { management } \\
\text { success }\end{array}$ & $\begin{array}{l}\text { Authority } \\
\text { Prov. and } \\
\text { Imp. On } \\
\text { Int. } \\
\text { per.Rel. }\end{array}$ & $\begin{array}{l}\text { Personality } \\
\text { Characteristics }\end{array}$ & $\begin{array}{l}\text { Family } \\
\text { Life }\end{array}$ & $\begin{array}{l}\text { Objectivity } \\
\text { And Equal } \\
\text { Treatment }\end{array}$ & \\
\hline 47 & 53 & $\begin{array}{l}\text { Female school } \\
\text { administrators have more } \\
\text { masculine behaviours than } \\
\text { female teachers. }\end{array}$ & & .71 & & & & .77 \\
\hline 48 & 55 & $\begin{array}{l}\text { Female school } \\
\text { administrators try to } \\
\text { behave like men to look } \\
\text { stronger. }\end{array}$ & & .67 & & & & .76 \\
\hline 44 & 50 & $\begin{array}{l}\text { There is more conflict/envy } \\
\text { between female school } \\
\text { administrators and female } \\
\text { teachers. }\end{array}$ & & .66 & & & & .76 \\
\hline 51 & 58 & $\begin{array}{l}\text { The students do not respect } \\
\text { the female school } \\
\text { administrators as much as } \\
\text { the male school } \\
\text { administrators. }\end{array}$ & & .64 & & & & .72 \\
\hline 43 & 49 & $\begin{array}{l}\text { Gossip in the schools of } \\
\text { female school } \\
\text { administrators is more } \\
\text { prominent than in the } \\
\text { schools of male managers. }\end{array}$ & & .58 & & & & .74 \\
\hline 52 & 59 & $\begin{array}{l}\text { When families come to } \\
\text { school, they want to meet } \\
\text { with a male school } \\
\text { administrator instead of the } \\
\text { female school } \\
\text { administrator. }\end{array}$ & & .57 & & & & .63 \\
\hline 46 & 52 & $\begin{array}{l}\text { Interpersonal jealousy is } \\
\text { experienced more in } \\
\text { schools managed by female } \\
\text { school administrators. }\end{array}$ & & .57 & & & & .81 \\
\hline 49 & 56 & $\begin{array}{l}\text { It is unpredictable how } \\
\text { female school } \\
\text { administrators will behave } \\
\text { in the face of administrative } \\
\text { problems. }\end{array}$ & & .56 & & & & .73 \\
\hline 45 & 51 & $\begin{array}{l}\text { Interpersonal conflicts are } \\
\text { more common in schools } \\
\text { managed by female school } \\
\text { administrators. }\end{array}$ & & .55 & & & & .81 \\
\hline 57 & 64 & $\begin{array}{l}\text { Female school } \\
\text { administrators } \\
\text { envied by female teachers } \\
\text { more than male school } \\
\text { administrators. }\end{array}$ & & .47 & & & & .68 \\
\hline 59 & 66 & $\begin{array}{l}\text { Female school } \\
\text { administrators behave } \\
\text { more unreliable than male } \\
\text { school administrators in } \\
\text { interpersonal relations. }\end{array}$ & & & .78 & & & .78 \\
\hline 60 & 67 & $\begin{array}{l}\text { Female school } \\
\text { administrators are more } \\
\text { likely to be smug than male } \\
\text { school administrators. }\end{array}$ & & & .68 & & & .78 \\
\hline 55 & 62 & $\begin{array}{l}\text { Female school } \\
\text { administrators attribute the } \\
\text { achievements to themselves }\end{array}$ & & & .66 & & & .78 \\
\hline
\end{tabular}


International Journal of Asian Education, Vol. 2, No. 3, September 2021

\begin{tabular}{|c|c|c|c|c|c|c|c|c|}
\hline \multirow[b]{2}{*}{$\begin{array}{c}\text { Final } \\
\text { Form } \\
\text { No. }\end{array}$} & \multirow[b]{2}{*}{$\begin{array}{l}\text { Pre- } \\
\text { form } \\
\text { No. }\end{array}$} & \multirow[b]{2}{*}{ Items } & \multicolumn{5}{|c|}{ Sub-Factors } & \multirow{2}{*}{$\begin{array}{l}\text { Item Total } \\
\text { Correlations }\end{array}$} \\
\hline & & & $\begin{array}{l}\text { General } \\
\text { management } \\
\text { success }\end{array}$ & $\begin{array}{l}\text { Authority } \\
\text { Prov. and } \\
\text { Imp. On } \\
\text { Int. } \\
\text { per.Rel. }\end{array}$ & $\begin{array}{l}\text { Personality } \\
\text { Characteristics }\end{array}$ & $\begin{array}{l}\text { Family } \\
\text { Life }\end{array}$ & $\begin{array}{l}\text { Objectivity } \\
\text { And Equal } \\
\text { Treatment }\end{array}$ & \\
\hline & & $\begin{array}{l}\text { and do not share them with } \\
\text { their employees. }\end{array}$ & & & & & & \\
\hline 53 & 60 & $\begin{array}{l}\text { Female school } \\
\text { administrators are more } \\
\text { hypocritical than male } \\
\text { school administrators. }\end{array}$ & & & .64 & & & .74 \\
\hline 61 & 68 & $\begin{array}{l}\text { When women become } \\
\text { school administrators, they } \\
\text { have more fear of being } \\
\text { alone than male school } \\
\text { administrators. }\end{array}$ & & & .63 & & & .75 \\
\hline 56 & 63 & $\begin{array}{l}\text { Female school } \\
\text { administrators reflect their } \\
\text { personal problems on their } \\
\text { jobs more than male school } \\
\text { administrators. }\end{array}$ & & & .52 & & & .79 \\
\hline 58 & 65 & $\begin{array}{l}\text { Female school } \\
\text { administrators are not open } \\
\text { to criticize as much as male } \\
\text { school administrators. }\end{array}$ & & & .52 & & & .76 \\
\hline 54 & 61 & $\begin{array}{l}\text { Female school } \\
\text { administrators are more } \\
\text { capricious than male school } \\
\text { administrators. }\end{array}$ & & & .51 & & & .79 \\
\hline 34 & 39 & $\begin{array}{l}\text { Female school } \\
\text { administrators neglect their } \\
\text { families. }\end{array}$ & & & & .76 & & .78 \\
\hline 32 & 37 & $\begin{array}{l}\text { Female school principals } \\
\text { give priority to their family } \\
\text { lives, so works get } \\
\text { disrupted. }\end{array}$ & & & & .68 & & .82 \\
\hline 33 & 38 & $\begin{array}{l}\text { Female school } \\
\text { administrators cannot } \\
\text { succeed without sacrificing } \\
\text { their private lives. }\end{array}$ & & & & .66 & & .78 \\
\hline 35 & 40 & $\begin{array}{l}\text { Female school } \\
\text { administrators reflect their } \\
\text { family problems more than } \\
\text { male school administrators. }\end{array}$ & & & & .64 & & .84 \\
\hline 31 & 36 & $\begin{array}{l}\text { Female school } \\
\text { administrators carry the } \\
\text { works of their family } \\
\text { individuals to schools more } \\
\text { than male school } \\
\text { administrators. }\end{array}$ & & & & .63 & & .83 \\
\hline 30 & 35 & $\begin{array}{l}\text { The lives of female } \\
\text { administrators are more } \\
\text { irregular than the family life } \\
\text { of women teachers. }\end{array}$ & & & & .60 & & .67 \\
\hline 36 & 41 & $\begin{array}{l}\text { Female school } \\
\text { administrators cannot } \\
\text { balance the family-work } \\
\text { balance as much as male } \\
\text { managers. }\end{array}$ & & & & .59 & & .83 \\
\hline 4 & 4 & $\begin{array}{l}\text { Female school } \\
\text { administrators make more } \\
\text { distinctions between their }\end{array}$ & & & & & .77 & .76 \\
\hline
\end{tabular}




\begin{tabular}{|c|c|c|c|c|c|c|c|c|}
\hline \multirow[b]{2}{*}{$\begin{array}{l}\text { Final } \\
\text { Form } \\
\text { No. }\end{array}$} & \multirow[b]{2}{*}{$\begin{array}{l}\text { Pre- } \\
\text { form } \\
\text { No. }\end{array}$} & \multirow[b]{2}{*}{ Items } & \multicolumn{5}{|c|}{ Sub-Factors } & \multirow{2}{*}{$\begin{array}{l}\text { Item Total } \\
\text { Correlations }\end{array}$} \\
\hline & & & $\begin{array}{l}\text { General } \\
\text { management } \\
\text { success }\end{array}$ & $\begin{array}{l}\text { Authority } \\
\text { Prov. and } \\
\text { Imp. On } \\
\text { Int. } \\
\text { per.Rel. }\end{array}$ & $\begin{array}{l}\text { Personality } \\
\text { Characteristics }\end{array}$ & $\begin{array}{l}\text { Family } \\
\text { Life }\end{array}$ & $\begin{array}{l}\text { Objectivity } \\
\text { And Equal } \\
\text { Treatment }\end{array}$ & \\
\hline & & $\begin{array}{l}\text { employees than male school } \\
\text { administrators. }\end{array}$ & & & & & & \\
\hline 3 & 3 & $\begin{array}{l}\text { Female school } \\
\text { administrators prioritize } \\
\text { their individual relations in } \\
\text { management more than } \\
\text { male managers. }\end{array}$ & & & & & .74 & .73 \\
\hline 2 & 2 & $\begin{array}{l}\text { Working with a female } \\
\text { school administrator can } \\
\text { have a negative impact on } \\
\text { male employees. }\end{array}$ & & & & & .70 & .68 \\
\hline 6 & 6 & $\begin{array}{l}\text { Female school } \\
\text { administrators pay close } \\
\text { attention to those who } \\
\text { establish close personal } \\
\text { relationships with } \\
\text { themselves more than male } \\
\text { administrators do. }\end{array}$ & & & & & .70 & .79 \\
\hline 7 & 7 & $\begin{array}{l}\text { Female school } \\
\text { administrators show favour } \\
\text { to flatterers more than male } \\
\text { administrators do. }\end{array}$ & & & & & .70 & .72 \\
\hline 5 & 5 & $\begin{array}{l}\text { Female school } \\
\text { administrators show an } \\
\text { undesirable sensuality } \\
\text { while doing their jobs. }\end{array}$ & & & & & .65 & .73 \\
\hline & & (Rotated) Eigenvalues & 8.909 & 5.963 & 5.638 & 5.457 & 5.005 & \\
\hline & & $\begin{array}{l}\text { (Rotated) Explained } \\
\text { variance }(\%)\end{array}$ & 19.797 & 13.190 & 12.529 & 12.127 & 11.122 & \\
\hline & & Cumulative variance (\%) & & & 68.765 & & & \\
\hline & & Cronbach's Alpha & .96 & .94 & .93 & .94 & .90 & \\
\hline & & $\begin{array}{l}\text { Cronbach's Alpha (For all } \\
\text { items) }\end{array}$ & & & .98 & & & \\
\hline
\end{tabular}

Since the items included in The Evaluation Scale of Female School Administrators aim to reveal the negative opinions about the female school administrator, it consists of negative statements about the evaluation of female school administrators. For this reason, the increase in the score of the participant who answered the scale shows that he/she has made a negative evaluation (and/or has stereotypes/prejudices) towards the female school administrator.

According to Table 1, the scale appears to have a five-factor structure. The first factor consists of 14 items, and the factor loading values of these items are between. 74 and .55; item-total correlations ranged from .86 to .70. The Cronbach's Alpha reliability coefficient of this factor was calculated at 96 . According to the content of the substances under the factor, it was concluded that this factor could be called "General Management Success" of women administrators.

There are ten items under the second factor. The factor loading values for these items are between .71 and .47; item-total correlations are between .81 and .63. The Cronbach's Alpha reliability coefficient of this factor was calculated as .94. When the items under the factor were evaluated in their contents, it was decided that this factor could be called "Authority Provision and Impact on Interpersonal Relations" of female administrators.

The third factor consists of 8 items. Item factor loadings are between. 78 and. 51; item-total correlations are between. 79 and. 74. The Cronbach's Alpha reliability coefficient of this factor is. 93. 
Considering the content of the substances in the factor, it was thought that this factor could be called the "Personality Characteristics" of female administrators.

The fourth factor consists of 7 items. Factor load values .76 - .59; item-total correlations are between. 84 - .67. The Cronbach's Alpha reliability coefficient of this factor is. 94. According to the content of the substances in the factor, this factor is related to female administrators' "Family Life".

The last factor consists of 6 items. Factor loading values of the items are between. 77 and. 65; item-total correlations ranged from. 79 to. 68. The Cronbach's Alpha reliability coefficient is. 90 for this factor. The substance contents of the factor were found to be related to the "Objectivity And Equal Treatment" of female administrators.

After varimax rotation, the variances explained by the five factors were $19.797 \%$ for the first factor, $13.190 \%$ for the second factor, $12.529 \%$ for the third factor, $12.127 \%$ for the fourth factor, and $11.122 \%$ for the last factor. These five factors explained $68.765 \%$ of the total variance. The scale was transformed into the final questionnaire at the end of the exploratory factor analysis, and the sub-factors of the "The Evaluation Scale of Female School Administrators" and the numbers of the items in these factors are given in Table 2 .

\section{Table 2. Sub-Factors and Item Numbers of The Evaluation Scale of Female School Administrators*}

\begin{tabular}{lr}
\hline \multicolumn{1}{c}{ Factor Name } & Item No \\
\hline General Management Success & 16, 14, 22, 21, 23, 10, 9, 13, 19, 20, 24, 27, 15, 8 \\
Authority Provision and Impact on Interpersonal & $47,48,44,51,43,49,46,52,45,57$ \\
Relations & \\
Personality Characteristics & $59,60,55,53,61,56,58,54$ \\
Family Life & $34,32,35,33,36,31,30$ \\
Objectivity And Equal Treatment & $4,3,2,6,7,5$ \\
\hline *Here are the item numbers in the "Final Form" distributed under six factors before the last factor analysis. Researchers can be \\
renumbered the scale items with consecutive numbers as 1-14 General Management Success; 15-24 Authority Provision and Impact \\
on Interpersonal; 25-32 Personality Characteristics; 33-39 Family Life and 40-45 Objectivity And Equal Treatment.
\end{tabular}

\section{CONCLUSION}

In this study, a scale that can measure the evaluations of teachers about female administrators and the stereotypes that female administrators face in the school organization were formed. As a result of the factor analysis, the total variance explained by the scale was calculated as $68.765 \%$. In this respect, it can be said that the scale's structure is validated. According to the content of the substances distributed to the sub-factors by factor analysis, 14 items included in the first factor were named "General Management Success"; 10 items in the second factor named "Authority Provision and Impact on Interpersonal Relationships"; 8 items in the third factor were named "Personality Characteristics"; 7 items in the fourth factor were named "Family life," and six items in the fifth factor were named "Objectivity And Equal Treatment" of female administrators. The Cronbach's alpha coefficient was calculated as .98, and $.96, .94, .93, .94$, and .90 for the sub-factors respectively. It can be said that this scale, which was developed in this way, can be used as a valid and reliable measurement tool in revealing the evaluations of teachers towards female school administrators.

When the items of the scale are considered together with the demographic variables of the teacher's condition of working or not working together with female school administrators in their schools, the scale can measure as well as assessing teachers' evaluations of female school administrators who are currently working with them; also the scale can be used to reveal the prejudices towards female school administrators by these teachers who do not work with the female school administrators. On the other hand, this scale was developed by working on elementary school teachers. If the scale is used with teachers working in different teaching levels and types and validity and reliability studies will be repeated, these will increase the scale's validity and reliability.

\section{ACKNOWLEDGMENT}

This study is a part of the author's PhD thesis. 


\section{Funding and Conflicts of Interest:}

The authors declare that there is no funding and conflicts of interest for this article.

\section{REFERENCES}

Abrams, D. (2010). Processes of prejudice: Theory, evidence, and intervention. Equality and Human Rights Commission Research Report, No: 56, Manchester: Centre for the Study of Group Processes, University of Kent.

Acker, J. (2009). From glass ceiling to inequality regimes. Sociologie du Travail, 51, 199-217.

Bodenhausen, G. V. and Richeson, J. A. (2010). Prejudice, stereotyping, and discrimination. In Baumeister, R. F. \& Finkel, E.J. (Eds.), Advanced social psychology: The state of the science. (pp. 341-383). United Kingdom: Oxford University Press.

Büyüköztürk, Ş. (2007). Sosyal bilimler için veri analizi el kitabı: İstatistik, araştırma deseni, SPSS uygulamaları ve yorum. (7. Baskı). [Handbook of data analysis for social sciences: Statistics, research design, SPSS applications and interpretation. (7th Edition)]. Ankara: Pegem A Yayıncllık.

Çokluk, Ö., Şekercioğlu, G. ve Büyüköztürk, Ș. (2010). Sosyal bilimler için çok değişkenli istatistik: SPSS Ve LISREL uygulamaları. (1. Baskı). [Multivariate statistics for social sciences: SPSS and LISREL applications. (1 ${ }^{\text {st }}$ Edition)]. Ankara: Pegem A Yayıncllık.

Dökmen, Z. Y. (2004). Toplumsal cinsiyet: Sosyal psikolojik açıklamalar. (1.Basım). [Gender: Social psychological explanations, (1 ${ }^{\text {st }}$ Edition).] İstanbul: Sistem Yayıncllık.

Mullins, L. J. (2006). Essentials of organizational behaviour. England: Pearson Education Limited.

Öztaş, U. ve Akın, O. (2009). Örgütsel çatışma yönetiminde cinsiyet farklılıkları: Antalya Serbest Bölgesinde bir araştırma. [Gender differences organizational conflict management: A research in Antalya free zone] Organizasyon ve Yönetim Bilimleri Dergisi, 1(1), 9-24.

Schmidt, T. M. \& Møller, A. L. (2011). Stereotypical barriers for women in management. Retrieved from http://pure.au.dk/portal/files/36185535/opgave til nettet.pdf

Tavşancıl, E. (2010). Tutumların ölçülmesi ve SPSS ile veri analizi. [Measurement of attitudes and data analysis with SPSS]. Ankara: Nobel Yayın Dağıtım.

Tüzel, E. (2014). Eğitim Örgütlerinde Kadın Yöneticilerin Kariyer Engellerinin İncelenmesi (Ankara İli Örneği), (PhD Thesis). [A Study on Career Barriers for Women Administrators in Educational Organizations (Example of Ankara), (Unpublished PhD dissertation)]. Gazi Üniversitesi, Eğitim Bilimleri Enstitüsü, Ankara-Türkiye.

Yost, E. B., and Herbert, T. T. (1998). Attitudes toward women as managers. The Pfeiffer Library Volume 12 (2nd ed.).

Yurdugül, H. (2005). Davranış bilimlerinde ölçek geliştirme çalışmaları için bazı ayrıntılar. [Some details for scale development studies in behavioral sciences] Retrieved from http://yunus.hacettepe.edu.tr/ yurdugul/3/indir/FA OrneklemGenislikleri 